\title{
STUDY CONCERNING THE POSSIBILITY OF GAMMA-SPECTROSCOPY METHOD TO DETERMINING THE TOTAL POTASSIUM IN SOILS
}

\author{
Leah Tamara ${ }^{1 *}$, Lozovaia Zoia ${ }^{2}$ \\ 'Institute of Pedology, Agrochemistry and Soil Protection "Nicolae Dimo", Chisinau-2070, Ialoveni str. 100, Moldova; Phone: \\ (+373-22) 28-48-61; Fax: (+373-22) 28-48-55; E-mail: tamaraleah09@gmail.com \\ ${ }^{2}$ Institute of Radiology, Gomel-246011, Fediuninschi, 16, Belarus
}

\begin{abstract}
The paper presents the results of scientific research related to development the specifically express-method for determining total potassium in podzolic soils from Belarus and chernozems from Moldova, based on the use of gamma-spectrometry. Determining the precise of the total content of potassium in the soils can be made directly in the field or laboratory by gamma-spectroscopy method using radiation detection of natural isotope ${ }^{40} \mathrm{~K}$. The conversion coefficient for podzolic soils of Belarus is $\mathrm{C}=0,00395$, for chernozems of Moldova - $\mathrm{C}=0,00337$.
\end{abstract}

Keywords: gamma-spectrometry, total potassium, ${ }^{40} \mathrm{~K}$, conversion coefficient, chernozems, podzolic soils.

\section{Introduction}

Scientific hypothesis of the project was proposed by the Institute of Radiology of Belarus and is based on the following assumptions, resulting from circumstantial evidence or priory expectations and there fore requires experimental validation:

1. Determining the precise total content of potassium in the soils can be made directly in the field or laboratory gamma-spectroscopy method using radiation detection of natural isotope ${ }^{40} \mathrm{~K}$.

2. The content of biologically available forms of potassium in soils is in quantitative relationship to the amount of total potassium in the soil, and this dependence can be expressed by a specific mathematical function, suitable for solving the problem of determination of mobile potassium in the soil in function of total content value.

Research potassium content in soils is an important task in agrochemistry nutrients and soil fertility [1-3]. Preliminary investigations carried out in Belarus and other research institutes have shown that there are all prerequisites for the elaboration and development of laboratory methods and method-express for determining global soil potassium content in the field remote using spectroscopic measurement equipment [4-8].

Gamma-spectroscopic method for determining in the laboratory and field the emission of radionuclide content of potassium-40 in soils was developed in the early of ' 90 by Scientific Research Institute for Agricultural Radiology of Belarus, now Institute of Radiology [9]. This method was widely used in the practice of Scientific Research Institute to mapping contamination levels post radiate territories with radionuclide from Chernobyl Nuclear Station.

Determination of potassium total by classical analysis method is very expensive. To perform this analysis is necessary to have laboratory platinum dishes and hydrofluoric acid, which is very toxic substance. The price of analysis, performed according to the method varies from $\$ 16,5$ to $\$ 25,0$. Using gamma-spectroscopic method (which is cheap and easy) to determine the total potassium will develop the cartograms of potassium content in the soils and preventive measures to reduce reserves of this important element in the arable layer of soil.

\section{Material and methods}

The possibility of determination total potassium in soils conforming radioactive isotope content by gammaspectroscopy method has been studied in soil samples collected from arable and under-arable layers of chernozems from North and Central part of Moldova. Dependence of mobile potassium content by total potassium content in chernozems of Moldova studied within the same samples by determining mobile forms of potassium after Macighin method [10].

The soil samples for develop a method of determining of total potassium in soil in dependence of content of ${ }^{40} \mathrm{~K}$ was made with consideration of their genesis and origin of parental rocks. The experimental range included 17 soil samples.

Determination of potassium forms in the soils was carried out according to following methods:

- Potassium total - classical method by Berzelius [11], the decompositions of soil with hydrofluoric acid and subsequent determination of potassium by flame photometry method.

- Potassium global - gamma-spectroscopic method with subsequent calculation of total potassium content in according to content of ${ }^{40} \mathrm{~K}$ isotope (expressed in Becquerel, Bq; $1 \mathrm{~Bq}=1 \mathrm{~s}^{-1}$ ), using the formula: $\mathbf{K}_{\mathbf{2}} \mathbf{O}, \mathbf{\%}=\mathbf{C} \cdot \mathbf{A}$, where: $\mathrm{C}$ - conversion coefficient, $\mathrm{A}-$ activity of isotope ${ }^{40} \mathrm{~K}$ in soil, $\mathrm{Bq} / \mathrm{kg}$. 
- Potassium mobile - Macighin method.

Value of conversion coefficient " $\mathrm{C}$ " in some specific cases, depending on sample size, precision analysis of gamma-spectrometry and classical methods, genesis characteristics of soils and parental rocks may be different. According to the calculations of researchers from Belarus the conversion coefficient $\mathrm{C}=0,00395$.

On the base of the difference between the average values of potassium content determined by the classical and the gamma-spectrometry methods $(\mathrm{C}=0,00395)$, the value of coefficient was modified using a conversion factor $(0,853)$ for further use in the chernozems, so the used coefficient " $\mathrm{C}$ " is equal to 0,00337 .

Spectrometric determination was made with "SILENA SNIP 301N" - distant spectrometer. The spectrometer is an information processor for spectroscopy research in environmental radiation monitoring, with high requirements for performing calculation during particularly difficult research and isotopic analysis in the field or laboratory. The spectrometer includes a detector (Nal-Tl) used in gamma-spectroscopy for qualitative and quantitative analysis with high precision and stability. The measures unit is impulse per second (imp/sec).

Data were statistically processed by dispersion and correlation method with software Excel 7.

\section{Results and discussions}

High costs and complexity of analytical determination of total potassium limited ability to monitor content of this element in soils and to develop appropriate cartograms. Research goal is to determine the possibility of assessing global potassium in soil in dependence of radioactive potassium- 40 isotope content by gamma-spectrometry determination of its in arable and under arable layers samples of chernozems.

To realization of this investigations were carried out in the field and made appropriate statistical samples of homogeneous soil relatively with genesis and originality of parental rocks. Based on laboratory results to determine the total potassium content in arable and under arable layer of soils by classical method (Berzelius, [11]), and gammaspectroscopic method ranges of variation have been made with the values of these determinations. For each variation series are calculated the average values $(\mathrm{X})$, standard deviation $(\sigma)$, coefficient of variation $(\mathrm{V}, \%)$, average error of the mean value $(\mathrm{m})$, relative value of average error $(\mathrm{P}, \%)$. Correlation coefficients were calculated $(\mathrm{r})$ in conformity by the values of global potassium content, obtained analytically and calculated in accordance of potassium- 40 isotope content. Parameters of soil composition and properties of the samples are presented in table 1.

The presented results confirm the proximity degree of investigated soils after composition size and parental rocks origin. The fallow chernozems have excellent physical properties, the arable - satisfactory. Arable soils, as results of agricultural use shall be subject to compaction.

According data presented in table 1, the fallow chernozems are characterized by very high content of humus and excellent chemical and physical properties. These soils are rich in total and mobile forms of potassium. Arable chernozems are moderate humificate and have satisfactory chemical properties. The total potassium content in these soils is high and mobile potassium content is moderate and high.

Correlative dependence between the values of classical determination and calculated values of global potassium (according potassium-40 isotope) is presented in table 2.

The value of the correlation coefficient equals $+0,69$, which confirms the presence of a large links. Researches confirm that sampling links of connection can be much higher. In this order, in processes of rating the gamma-spectroscopic method for determining radioactive potassium by detection of gamma rays from natural isotope of potassium K-40 and the parallel determination of potassium by classical method, it is necessary:

- to reduce the error of value to determine the isotope $\mathrm{K}-40$ two times, thus reducing the error of determining the value of global potassium from $0,40 \% \mathrm{~K}_{2} \mathrm{O}$ to $0,20 \% \mathrm{~K}_{2} \mathrm{O}$;

- to eliminate of random error analysis of soil samples in 2 or 3 repetition in determining of global potassium;

- a composition of homogeneous samples of soils for statistical processing of obtains results of total potassium determination and corrects to calculate the numerical value of coefficient " $\mathrm{C}$ ".

Comparing the results of 17 parallel determinations of global potassium content $\left(\mathrm{K}_{2} \mathrm{O}, \%\right)$ in one and the same soil samples with classical and calculated methods (in consideration with radioactive isotope $\mathrm{K}-40$, applying conversion coefficient $\mathrm{C}=0,00337$ for chernozems) has established the following differences:

- Less than $0,1 \% \mathrm{~K}_{2} \mathrm{O}-$ in 9 cases or $53 \%$ of the samples;

- From 0,1 to $0,2 \% \mathrm{~K}_{2} \mathrm{O}$ - in 5 cases or $30 \%$ of the samples;

- From 0,2 to $0,3 \% \mathrm{~K}_{2} \mathrm{O}$ - in 3 cases or $17 \%$ of the samples; 


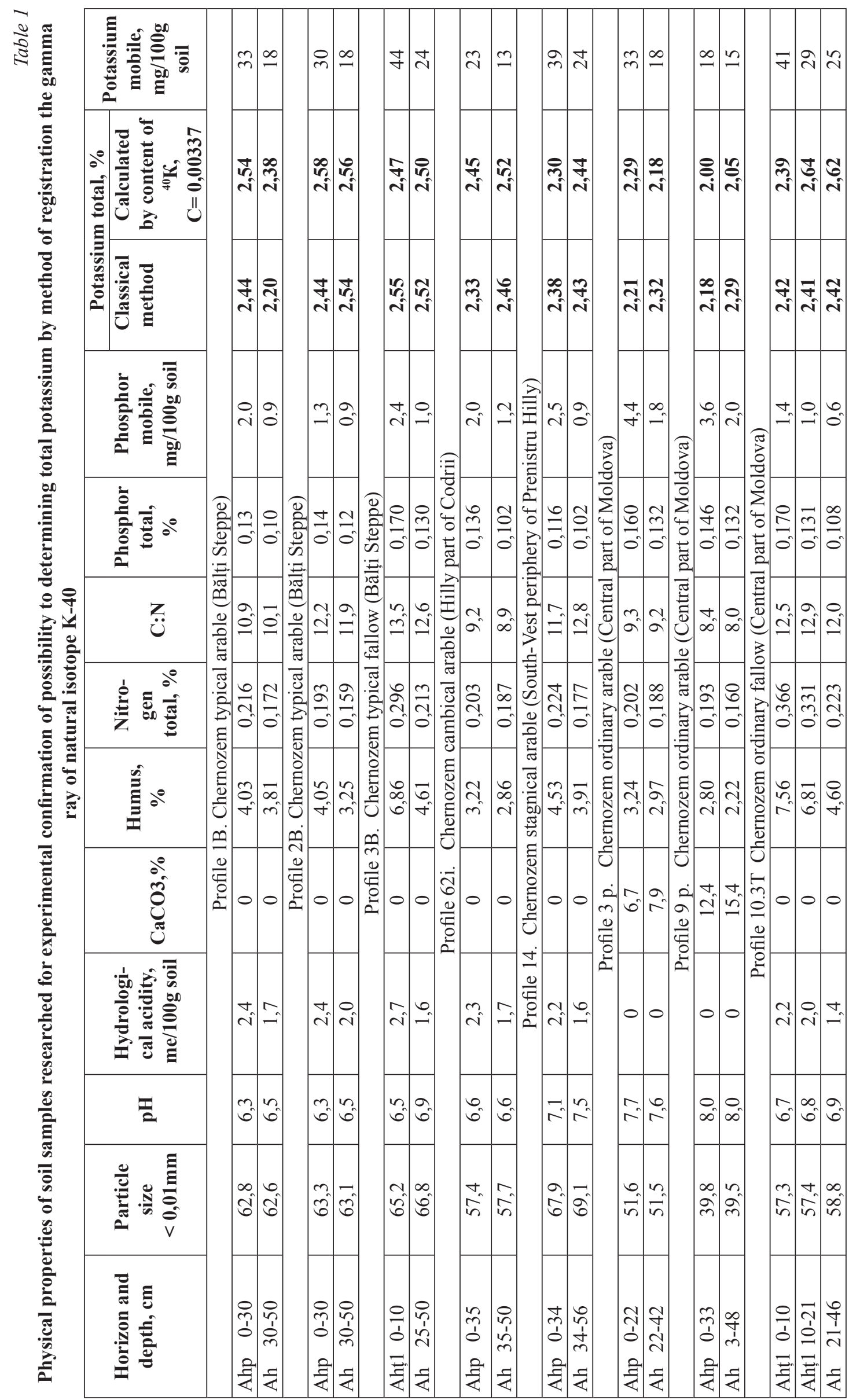


Correlation between values of total potassium content in chernozems, determining in parallel in the same samples by classical and gamma-spectroscopy methods

\begin{tabular}{|c|c|c|c|c|c|c|}
\hline \multirow{3}{*}{$\begin{array}{c}\text { Nr. of } \\
\text { profiles }\end{array}$} & \multirow{3}{*}{$\begin{array}{c}\text { Horizons and } \\
\text { depth, cm }\end{array}$} & \multicolumn{2}{|c|}{$\mathbf{K}_{2} \mathrm{O}$ total } & \multirow{2}{*}{\multicolumn{2}{|c|}{$\begin{array}{c}\text { Deviation from } \\
\text { average value, } \\
\Delta \mathbf{x}\end{array}$}} & \multirow{3}{*}{$\begin{array}{c}\text { Result of deviation } \\
\text { from average } \\
\text { comparative values }\end{array}$} \\
\hline & & \multirow{2}{*}{$\begin{array}{c}\text { Gamma- } \\
\text { spectroscopy } \\
\text { method, } \\
\mathrm{C}=\mathbf{0 , 0 0 3 3 7}(\mathbf{1})\end{array}$} & \multirow{2}{*}{$\begin{array}{l}\text { Classical } \\
\text { method } \\
(2)\end{array}$} & & & \\
\hline & & & & (1) & (2) & \\
\hline \multirow[t]{2}{*}{$1 \mathrm{~B}$} & $0-25$ & 2,54 & 2,44 & $+0,13$ & $+0,05$ & $+0,0065$ \\
\hline & $25-50$ & 2,38 & 2,20 & $-0,03$ & $-0,17$ & $+0,0051$ \\
\hline \multirow[t]{2}{*}{ 2B } & $0-30$ & 2,58 & 2,44 & $+0,17$ & $+0,05$ & $+0,0085$ \\
\hline & $30-50$ & 2,56 & 2,54 & $+0,15$ & $+0,15$ & $+0,0225$ \\
\hline \multirow[t]{2}{*}{ 3B } & Aht1 & 2,47 & 2,55 & $+0,06$ & $+0,16$ & $+0,0096$ \\
\hline & $30-50$ & 2,50 & 2,52 & $+0,09$ & $+0,13$ & $+0,0117$ \\
\hline \multirow[t]{2}{*}{$62 \mathrm{i}$} & $0-35$ & 2,45 & 2,40 & $+0,04$ & $+0,01$ & $+0,0004$ \\
\hline & $35-50$ & 2,52 & 2,46 & $+0,11$ & $+0,07$ & $+0,0077$ \\
\hline \multirow[t]{2}{*}{14} & $0-34$ & 2,30 & 2,38 & $-0,11$ & $-0,01$ & $+0,0011$ \\
\hline & Ahk $30-56$ & 2,44 & 2,43 & $+0,03$ & $+0,04$ & $+0,0012$ \\
\hline \multirow[t]{2}{*}{$3 p$} & Ahpk $\quad 0-30$ & 2,29 & 2,21 & $-0,12$ & $-0,18$ & $+0,0216$ \\
\hline & Ahpk2 30-50 & 2,18 & 2,32 & $-0,23$ & $-0,07$ & $+0,0161$ \\
\hline \multirow[t]{2}{*}{$9 p$} & Ahpk1 $0-33$ & 2,00 & 2,18 & $-0,41$ & $-0,21$ & $+0,0861$ \\
\hline & Ahpk2 33-48 & 2,05 & 2,29 & $-0,36$ & $-0,10$ & $+0,0360$ \\
\hline \multirow[t]{3}{*}{$10.3 \mathrm{~T}$} & Aht1 & 2,39 & 2,42 & $-0,02$ & $+0,03$ & $-0,0006$ \\
\hline & Aht2 10-21 & 2,64 & 2,41 & $+0,23$ & $+0,02$ & $+0,0046$ \\
\hline & $21-46$ & 2,62 & 2,42 & $+0,21$ & $+0,03$ & $+0,0063$ \\
\hline \multicolumn{2}{|c|}{ Average indexes } & $\mathrm{X} 1=2.41$ & $\mathrm{X} 2=2,39$ & $\sigma=0,19$ & $\sigma=0,11$ & 0,2444 \\
\hline
\end{tabular}

Note: $\boldsymbol{C}$ - the coefficient for recalculating the number of Becquerel in total potassium content $\left(\mathrm{K}_{2} \mathrm{O}\right) ; \boldsymbol{X}-$ average value; $\boldsymbol{\sigma}-$ standard deviation squared; $\boldsymbol{r}$-correlation coefficient; $\boldsymbol{r}=+\mathbf{0 , 6 9}$ (high correlation).

Very high and high coincidence of parallel determination results of global potassium by different methods is found in $83 \%$ cases, satisfactory - in $17 \%$ cases. Reducing the error in gamma-spectroscopic measurements, excluding the random errors in the determination of potassium in calibration process of new method, conducting research with gamma-spectroscopic method in homogeneous samples of soil, will offer the possibility and opportunity to significantly improve the precision of determining global potassium in soils by the method of calculation as K-40 isotope content.

The results of determining the total potassium in researched soils show that in most cases, the content in the arable layers is lower than in sub-arable layers. This investigation confirms that in case with non application potassium fertilizers, the total reserves of this element in the arable layer of soil will be reduced progressive.

Correlative dependence analysis of results to determine the global and mobile potassium content in chernozems of Moldova have confirmed the total lack of this dependence both in arable and sub-arable soil layers investigated separately.

From scientifically, this phenomenon can be explained. The quantity of total potassium depends essentially only by the content in network of crystalline minerals. This form of potassium is closely linked by mineral network and exchange reactions involved in weak, the element is immobile and inaccessible to plants.

The content of mobile potassium in soil is very small $-20-50 \mathrm{mg} / 100 \mathrm{~g}$ soil, which is equal to $0,02-0,05 \%$ of soil mass. These small amounts of mobile potassium in the soil almost no influence the total content of this element. On the other hand, the accumulation of mobile potassium forms in the soils is different. The main components, those participate in the accumulation of mobile potassium in soil are:

- capacity of substances biological circuit;

- intensity of minerals alteration processes;

- the total content of potassium in the crystalline network of soil minerals and its part to involved in cation potassium exchange process;

- $\quad$ anthropogenic factor - the quantity of fertilizes applied in soils.

From the above, it appears that components of replenishment of soil potassium reserves are independent and not depend on each other, and the total content of potassium in the soil.

It must be recognized that the content of potassium mobile forms accessible to plants, is not directly depending on the quantity of total potassium in the soil. Assumed dependence is not statistically confirmed and can not be expressed 
by a mathematical function determinate adequate to solve the problem of determining the mobile potassium content in soils on the function of total potassium content value.

\section{Conclusions}

Development of a simple and inexpensive gamma-spectroscopy method for determining global potassium in soil will provide an opportunity to draw cartograms of total potassium content and elaborate preventive measures to reduce the reserves of this important physiological element in soils.

The content of biological accessible forms of potassium in the soils is not in direct quantitative dependence to total potassium content and can not be expressed by a specific mathematical function, able to solve the problem of determining the mobile potassium content in function by global value.

Correlative dependence between the values of global potassium obtain by classical and calculated method (in function of K-40 isotope content) estimated by the correlation coefficient, confirms the presence of a large leak links between them.

The link between the results of the determination of global potassium by mentioned method must be much higher. To this end, in the charging gamma-spectroscopy method for determining of potassium in accordance with determination results of potassium by classical method must:

- to reduce the error value to determine the isotope $\mathrm{K}-40$ two times, in this way decrease the value error in determining the global potassium from $\pm 0,40 \% \mathrm{~K}_{2} \mathrm{O}$ to $\pm 0,20 \% \mathrm{~K}_{2} \mathrm{O}$.

- to exclude random errors by determining the 2 or 3 repetitions of total potassium in soil samples used to construct the sample for accurate calculation of the numerical value of the conversion coefficient "C".

For potassium determinations statistical processing of results is necessary to investigate homogeneous soil samples, composed after this genesis and agricultural use; the origin of the appearance, mineralogical composition of parental rocks.

The results of determining potassium in investigated soils shows that in most cases its content in the arable layers is less than in sub-arable. This confirms that in condition whit non application of potassium fertilizers in soil, the total reserves of potassium in the arable layer of soil will be reduce gradually.

\section{Acknowledgements}

This work was supported by the bilateral project 313. BF: "Dependence determination of total and biologic accessible potassium content in podzolic soils of Belarus and chernozems of Moldova".

\section{References}

[1]. Андреева, Е.А. Радиоактивность почв и определение калия радиометрическим методом. Почвоведение, 1960, №5. Активность радионуклидов в объемных образцах. Методика выполнения измерений на гаммаспектрометре: рекомендация: МИ 2143-91: утв. 28.12.1990. 1990.

[2]. Кузнецов, А.В. и др. Методические указания по контролю радиоактивным загрязнением сельскохозяйственных угодий, прилегающих к атомным станциям. М.: ЦИНАО, 1990. 16 с.

[3]. Самохвалов, С.Г. и др. Методические указания по проведению радиологических исследований на контрольных участках. М.: ЦИНАО, 1982. 25 с.

[4]. Вешко, Э.И. Естественная радиоактивность почв Харьковской области. В сб.: Радиоактивность почв и методы её определения. М.: Наука, 1966. С.212-219.

[5]. Инструкции и методические указания по оценке радиационной обстановки на загрязненной территории. В сб.: Межвед. комис. по радиац. контролю природной среды; под ред. Ю.А. Израэля. М., 1989. - 200 с.

[6]. Ковалевский, А. Усовершенствование радиометрического метода определения калия в порошковых пробах. Мин-во геол. и охраны недр СССР. В сб. научно-техн. информации, №5, 1957. 119 с.

[7]. Прохорычева, Н.П.; Агапова Т.Н.; Моторина Л.Н. Содержание калия-40 в почвах берегов водоемов и лугов отдельных районов Калининградской области [Радионуклид]. С.139-145 В сб.: Теоретические и прикладные аспекты биоэкологии. Калинингр. гос. ун-т. Калининград, 2003.

[8]. Сельскохозяйственная радиоэкология / Под ред. Р.М. Алексахина, Н.А. Корнеева. М.: Экология, 1991. $400 \mathrm{c}$.

[9]. Агеец, В.Ю. Система радиоэкологических контрмер в агросфере Беларуси. Республиканское научноисследовательское унитарное предприятие «Институт радиологии». МН., 2001. 250 с.

[10]. Аринушкина Е.В. Руководство по химическому анализу почв. М.: Изд-во МГУ, 1970. 470 с.

[11]. Батунер, Л.М., Позин М.Е. Математические методы в химической технике. Л., Гос. н.-т. изд-во хим. литры, 1960. 